\title{
ПОСЛУГА ЯК СИСТЕМОУТВОРЮЮЧИЙ ФАКТОР РОЗВИТКУ І УПРАВЛІННЯ ОЗДОРОВЧИМ ТУРИЗМОМ
}

\begin{abstract}
В статті проведено дослідження щзодо сутності категорії «послуга», яка розглядається як системоутворюючий фактор розвитку оздоровчого туризму. На основі узагальнення закордонних й вітчизняних теоретичних досліджень виділено взаємозв'язки та відмінності визначень $і$ встановлено, щзо послугу необхідно розглядати як економічний феномен, суспільний феномен, соціальний феномен $i$ об'єкт управління з відповідним змістовним наповненням. Визначено складові послуги, як предмета споживання, до яких віднесено: результати послуги, прочес обслуговування $i$ його характеристики, фізичне оточення й система доставки послуги, зовнішній вигляд і поведінка сервісного персоналу й інших споживачів, час надання послуги.

3 метою встановлення специифічних властивостей послуги, як фактору розвитку і управління оздоровчим туризмом розглянуто модель складових послуги, яку запропоновано доповнити характеристикою, щзо пов'язана з особливостями створення значимої цінності для споживача. Запропоновано складові послуги як об'єкта управління доповнити властивістю «час», необхідним для одержання доступу до послуги й для надання послуги в иүілому, щзо у свою чергу можна розглядати як додаткову вигоду від одержання послуги.

На основі уточненого поняття «послуга оздоровчого туризму», виділено ї̈ властивості, до яких віднесено: соціальні (оздоровчо-профілактичні, оздоровчо-лікувальні функиіі), суспільні (формування всебічно й гармонійно розвиненої особистості, благоустрій середовища) та економічні функції (реалізачія фінансових завдань приватних підприємств, організачій, збільшення доходів бюджетів різних рівнів управління та ін.); загальні ознаки і відмінні ознаки, щчо формують рівень цінності послуги в певний момент часу; змістовне наповнення, що дозволяє розділити послуги за оздоровчопрофілактичним та оздоровчо-лікувальним напрямами та створити рівень задоволеності споживача.

Ключові слова: послуга, виробництво, споживання, цінність, оздоровчий туризм, управління.
\end{abstract}

Н. В. ШАНДОВА Херсонский национальный технический университет ORCID: 0000-0002-6278-1143

А. В. ТАРАСЮК

Херсонский национальный технический университет ORCID: 0000-0001-7765-502X

\section{УСЛУГА КАК СИСТЕМООБРАЗУЮЩИЙ ФАКТОР РАЗВИТИЯ И УПРАВЛЕНИЯ ОЗДОРОВИТЕЛЬНЫМ ТУРИЗМОМ}

В статье проведено исследование сущности категории «услуга», которая рассматривается как системообразующий фактор развития оздоровительного туризма. На основе обобщения заграничных и отечественных теоретических исследований вылелены взаимосвязи и отличия определений и установлено, что услугу необходимо рассматривать как экономический феномен, общественньй феномен, социальный феномен и объект управления с соответствующим содержательным наполнением. Определены составляющие услуги, как предмета потребления, к которым отнесены: результаты услуги, процесс обслуживания и его характеристики, физическое окружение и система доставки услуги, внешний вид и поведение сервисного персонала и других потребителей, время предоставления услуги.

С иелью установления специфических свойств услуги, как фактора развития и управления оздоровительным туризмом исследована модель составляющих услуги, которую предложено дополнить характеристикой, которая связана с особенностями создания значимой ценности для потребителя. Предложено составляющие услуги, как объекта управления, дополнить категорией «время», необходимое для получения доступа к услуге и для предоставления услуги в целом, что, в свою очередь, можно рассматривать как дополнительную выгоду от получения услуги. 
На основе уточненного понятия «услуга оздоровительного туризма», выделень ее свойства, $\kappa$ которым отнесены: сочиальные (оздоровительно-профилактические, оздоровительно-лечебные функиии), общественные (формирование всесторонне и гармонично развитой личности, благоустройство среды) и экономические функиии (реализаџия финансовых задач частных предприятий, организащий, увеличение доходов бюджетов разных уровней управление и др.); общие признаки и отличительные признаки, которые формируют уровень иенности услуги в определенный момент времени; содержательное наполнение, что позволяет разделить услуги за оздоровительнопрофилактические и оздоровительно-лечебные направления и создать уровень удовлетворенности потребителя.

Ключевые слова: услуга, производство, потребление, чуенность, оздоровительный туризм, управление.

N. V. SHANDOVA

Kherson National Technical University ORCID: 0000-0002-6278-1143

A. V. TARASIUK

Kherson National Technical University ORCID: 0000-0001-7765-502X

\section{SERVICE AS A SYSTEM-FORMING FACTOR OF HEALTH TOURISM DEVELOPMENT AND MANAGEMENT}

The article studies the essence of the category "service", which is considered as a system-forming factor in the development of health tourism. On the basis of generalization of foreign and domestic theoretical studies, the interrelationships and differences in the definitions of "service" are highlighted. It has been established that a service must be considered as an economic phenomenon, a social phenomenon, a social phenomenon and an object of management with an appropriate content. The components of the service, as a consumer item, are defined, which include: the results of the service, the service process and its characteristics, the physical environment and the service delivery system, the appearance and behavior of the service personnel and other consumers, the time of service provision.

In order to establish the specific properties of the service as a factor in the development and management of health tourism, a model of the components of the service has been investigated, which is proposed to be supplemented with a characteristic that is associated with the features of creating significant value for the consumer. It is proposed that the components of the service, as a control object, be supplemented with the category "time" required to gain access to the service and to provide the service as a whole, which, in turn, can be considered as an additional benefit from receiving the service.

On the basis of the refined concept of "health tourism service", its properties are highlighted, which include: social (health-improving and preventive, health-improving and therapeutic functions), public (formation of a comprehensively and harmoniously developed personality, improvement of the environment) and economic functions (implementation of financial tasks of private enterprises, organizations, an increase in budget revenues of different levels of management, etc.); common features and distinctive features that form the level of value of the service at a certain point in time; meaningful content, which allows you to divide services into health-improving and preventive and health-improving areas and create a level of customer satisfaction.

Key words: service, production, consumption, value, health tourism, management.

\section{Постановка проблеми}

3 огляду на необхідність переосмислення ролі туристичної галузі в інтеграційних та глобалізаційних процесах держави, трансформації структури національної економіки 3 метою збільшення третинного сектору, а саме обсягів надання послуг, та створення умов покращення стану здоров'я населення, виникає потреба дослідження змістовного наповнення категорії «послуга оздоровчого туризму» для подальшого створення базису стимулювання розвитку туристичної діяльності і оздоровчого туризму.

\section{Аналіз останніх досліджень і публікацій}

Дослідженню проблем керування організаціями сфери послуг присвячені роботи багатьох закордонних і вітчизняних учених: Д. Белла, Ю. Бурило, Х. Ворачек, Ф. Котлера, К. Хаксевера й Р. Рассела і ін. Дослідження, пов'язані з вивченням споживчих властивостей послуг і побудовою моделі їх якості представлені в роботах Б. Едвардсона [14],. К. Гренрооса [15], Р. Джадда [16] і ін. Теоретичні і практичні аспекти розвитку ринку туристичних послуг розглянуто в працях О. Бейдика, В. Герасименка, М. Біржакова, О. Воскресенської, С. Макаренка, Н. Олійник та ін. 
Разом $з$ тим, деякі аспекти змістовного наповнення категорії послуга оздоровчого туризму вивчені недостатньо, не враховують ситуаційну основу послуги як об'єкта управління, що потребує додаткового вивчення з урахуванням специфіки оздоровчого туризму.

\section{Формулювання мети дослідження}

Метою статі є дослідження сутності послуги як системоутворюючого фактору управління i розвитку оздоровчого туризму.

\section{Викладення матеріалу дослідження}

Послуга в системі розвитку і управління оздоровчим туризмом виступає головним фактором, прояв якого реалізується у наступному:

- надання послуг є гарантією функціонування оздоровчого туризму і збереження зв'язків між його елементами;

- послуга сприяє збалансованості інтересів і елементів оздоровчого туризму в межах дестинації;

- існує попит на інноваційні технології оздоровчих послуг.

Для виявлення сутності послуг оздоровлення, розглянемо зміст поняття «послуга».

Базове поняття «service» в перекладі 3 англійської може мати значення «послуга», «обслуговування», «служба», «допоміжний», «допомога», «зв'язок», «сфера діяльності», експлуатація», «робота».

Огляд закордонних й вітчизняних теоретичних досліджень показує, що в доіндустріальному суспільстві переважали домашні або особисті послуги, а в індустріальному суспільстві акцент зміщається убік послуг, які відіграють допоміжну роль стосовно виробництва, а також фінансових послуг. У постіндустріальному суспільстві, при кількісному збільшенні і якісній різноманітності галузей зберігаються усі раніше існуючі види послуг і з'являються нові послуги, більш складні та тісно переплетені із виробництвом. У зв'язку із чим, Д. Белл відзначив: «слово «послуга» не повинне викликати оманливих образів швидко приготовленої їжі й низькооплачуваних працівників; основними $€$ фінансові, професійні й конструкторські послуги, охорона здоров'я, освіта і соціальна сфера, і лише на останньому місці цієї шкали стоять побутові послуги» [2].

Питанням управління діяльністю в сфері вироблення і надання послуг присвячено праці вітчизняних і закордонних учених $[4,5,12,14,15,17,18]$. Але на думку Х. Ворачека не вироблено єдиного поняття «послуга», здатного охопити все різноманіття даного явища. У літературі зустрічається досить широкий діапазон думок з цього питання [5].

У таблиці 1 представлений аналітичний огляд підходів до трактування терміну «послуга».

\section{Деякі підходи до трактування терміну «послуга»}

Таблиця 1

\begin{tabular}{|c|c|c|}
\hline \\
\hline Джерело & Трактування & Основні положення \\
\hline Г. Ассель [1] & $\begin{array}{l}\text { Послуги - це невловимі блага, які здобуваються } \\
\text { споживачем, але не пов'язані із власністю }\end{array}$ & $\begin{array}{l}\text { нематеріальний характер } \\
\text { кінцевого } \\
\text { результату(блага), що } \\
\text { здобувається }\end{array}$ \\
\hline Ф. Котлер [8] & $\begin{array}{l}\text { Будь-який захід, діяльність або вигода, які одна сторона } \\
\text { може надати інший, і які в основному не відчутні й не } \\
\text { приводять до оволодіння чим-небудь }\end{array}$ & $\begin{array}{l}\text { зв'язок послуги й з дією, } \\
\text { i з результатом }\end{array}$ \\
\hline Л. Беррі [3] & $\begin{array}{l}\text { Послуга - це дія, робота, зусилля..., що має } \\
\text { нематеріальний характер, виробляється й споживається } \\
\text { одночасно й у багатьох випадках менш стандартизована й } \\
\text { єдино подібна, чим продукт }\end{array}$ & $\begin{array}{l}\text { дія, робота, зусилля } \\
\text { менш стандартизовані й } \\
\text { єдино подібні, чим } \\
\text { продукт }\end{array}$ \\
\hline $\begin{array}{l}\text { К. Гронроос } \\
{[15]}\end{array}$ & $\begin{array}{l}\text { Процес, що включає серію (або декілька) невловимих дій, } \\
\text { які по необхідності відбуваються при взаємодії між } \\
\text { покупцями й обслуговуючим персоналом, фізичними } \\
\text { ресурсами, системами підприємства - постачальника } \\
\text { послуг. Цей процес спрямований на вирішення проблем } \\
\text { покупця послуги }\end{array}$ & $\begin{array}{l}\text { процес, спрямований на } \\
\text { рішення } \quad \text { проблем } \\
\text { споживача послуги }\end{array}$ \\
\hline $\begin{array}{l}\text { Н. Федорченко } \\
{[12]}\end{array}$ & $\begin{array}{l}\text { Послуга - дія або сукупність дій (діяльність), об’єднаних } \\
\text { однією метою - створення корисного ефекту }\end{array}$ & $\begin{array}{lr}\text { діяльність } & 3 \\
\text { створення } \\
\text { ефекту }\end{array}$ \\
\hline Ю. Бурило [4] & $\begin{array}{l}\text { Послуга - дія або діяльність, корисний ефект від якої не } \\
\text { має матеріальної форми і споживається в процесі іiї } \\
\text { надання та невіддільний від неї }\end{array}$ & $\begin{array}{lr}\text { діяльність з } & \text { корисним } \\
\text { ефектом, шо } & \text { немає } \\
\text { матеріальної } & \text { форми } \\
\text { невіддільна } & \text { від } \\
\text { виконавця } & \end{array}$ \\
\hline
\end{tabular}




\begin{tabular}{|c|c|c|}
\hline Г. Шаркова [13] & $\begin{array}{l}\text { Послуга - корисний результат, що } \\
\text { послугоотримувач від послугонадавача, що може } \\
\text { виражатися у майновому характері, оскільки більшість } \\
\text { послуг є економічним підгрунтям. }\end{array}$ & $\begin{array}{lr}\text { благо, } & \text { яке } \\
\text { нематеріальне, } & \text { корисне, } \\
\text { невіддільне } & \text { від } \\
\text { виконавця } & \\
\end{array}$ \\
\hline Р. Джадд [16] & $\begin{array}{l}\text { Пропоновані на продаж послуги - це ринкова угода, } \\
\text { виконувана підприємством або підприємцем, де ціль } \\
\text { угоди відмінна від передачі власності (або права } \\
\text { власності) на матеріальний товар. }\end{array}$ & $\begin{array}{lr}\text { послуга, } & \text { як } \\
\text { угода } & \text { ринкова } \\
\text { цілями відмінними } \\
\text { власності } \\
\begin{array}{l}\text { матеріальний товар } \\
\text { передачі }\end{array} \\
\end{array}$ \\
\hline $\begin{array}{l}\text { Закон України } \\
\text { «ро захист } \\
\text { прав } \\
\text { споживачів» } \\
{[10]}\end{array}$ & $\begin{array}{l}\text { Послуга - це діяльність виконавця з надання (передання) } \\
\text { споживачеві певного визначеного договором } \\
\text { матеріального чи нематеріального блага, що здійснюється } \\
\text { за індивідуальним замовленням споживача для } \\
\text { задоволення його особистих потреб }\end{array}$ & $\begin{array}{lr}\text { діяльність } \quad 3 \quad \text { надання } \\
\text { нематеріального } \\
\text { матеріального блага }\end{array}$ \\
\hline $\begin{array}{l}\text { Класифікатор } \\
\text { видів } \\
\text { економічної } \\
\text { діяльності (ДК } \\
\text { 009:2010) [7] }\end{array}$ & $\begin{array}{l}\text { Послуги - це результат економічної діяльності, відносно } \\
\text { якого не можна встановити права власності. Послуги не } \\
\text { підлягають продажу окремо від процесу їх виробництва. } \\
\text { Момент завершення виробництва послуги збігається } 3 \\
\text { моментом надання їі споживачеві }\end{array}$ & $\begin{array}{l}\text { результат економічної } \\
\text { діяльності, невід'ємний } \\
\text { від процесу їх } \\
\text { виробництва. }\end{array}$ \\
\hline $\begin{array}{l}\text { Генеральна } \\
\text { угода про } \\
\text { торгівлю } \\
\text { послугами } \\
\text { (ГАТС) [6] }\end{array}$ & $\begin{array}{l}\text { Послуга - вид товару, тому вони підпадають під операції } \\
\text { торгівлі }\end{array}$ & вид товару \\
\hline
\end{tabular}

Джерело: узагальнено авторами за $[1,3,4,6,7,8,10,12,13,15,16]$

Аналіз підходів вітчизняних і закордонних дослідників до суті терміну «послуга» дозволяє виділити наступні аспекти при формуванні даного терміну стосовно до того чи іншого виду економічної діяльності:

- послуга - як вид діяльності;

- послуга - як вид економічних благ;

- послуга - як результат взаємодії декількох сторін;

- послуга - як вид дії;

- послуга - як товар;

- послуга - як процес.

Як видно, більшість визначень тісно взаємопов'язані. Відмінність визначень укладається, поперше, у тому, що автори характеризують послугу або як соціальне, або як економічне явище; по-друге, різні визначення акцентують увагу або на процесі надання послуги, або на їі результаті.

На нашу думку послугу необхідно розглядати як економічний феномен (об’єкт купівлі-продажу і економічних відносин), суспільний феномен (організована діяльність), соціальний феномен і об’єкт управління.

Економічний зміст послуги визначається якщо розглядати послугу як дію, а отже вона $\epsilon$ продуктом праці; а через те, що вона має корисний ефект, тобто, споживчу вартість, послуга визнається благом, яке є об'єктом купівлі-продажу і об'єктом цивільних правовідносин.

Суспільний зміст послуги розкривається наявністю діяльності, яка виражена у терміні «надання послуги», та представляє собою певну сукупність дій з надання (виробництва) послуг і потребує певної організаційної основи. Сукупність дій з надання послуги - це дії або операції з підготовки фінальної послуги до споживання, тобто, дії, що можуть виконуватися різними особами, що, в свою чергу, формує основу для суспільного поділу праці і обміну благами.

Соціальний зміст послуги - (соціальний феномен) пояснюється наявністю особистісних та суспільних взаємовідносин, тобто, наявністю особи або осіб, в інтересах яких відбуваються дії, а також корисність для них даних дій.

Дослідження визначень «послуга» (табл. 1) показують, що складовими послуги, як предмета споживання, є: результати послуги, процес обслуговування і його характеристики, фізичне оточення й система доставки послуги, зовнішній вигляд і поведінка сервісного персоналу й інших споживачів, час надання послуги. Б. Едвардсон [14] указує, що процес і результат послуги засновані на умовах у формі ресурсів (матеріально-технічних, адміністративних, людських), необхідних для надання послуги (рис. 1.). 


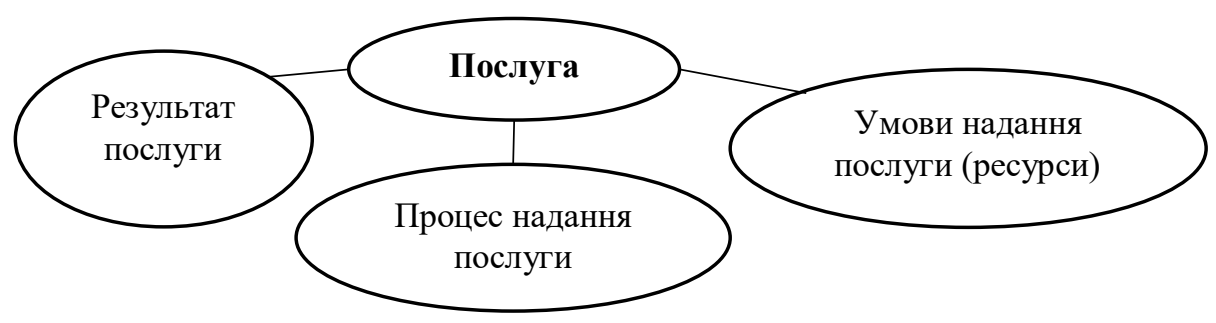

Рис. 1. Складові послуги як об’'єкта управління у відповідності за моделлю Б. Едвардсона Джерело: розроблено на основі [14]

В науковій літературі $[1,3,5,8,10,11,17,18]$ виділяють наступні властивості послуг:

- невловимий характер послуги, їі нематеріальність, що означає, що послуги практично неможливо продемонструвати, спробувати, транспортувати, упаковувати, дослідити до їхнього одержання;

- нерозривність процесу виробництва й споживання послуги, що означає, що послуга невіддільна від суб'єкта відносин, що ії надає, послуги не можна зробити взапас;

- неможливість збереження послуги, що означає, що послуги не можуть бути збережені для подальшої реалізації;

- мінливість якості виробництва й процесу споживання, що проявляється в тому, що задоволеність послугами суттєво залежить від того, хто їі надає, а також від місця, часу, способів іiі надання.

Але необхідно також відзначити, що корисна функція товару й послуги використовується споживачем під час актуалізації відповідної до потреби й цінність послуги пов'язана 3 можливістю ії одержання під час актуалізації потреби. Послуга не представляє цінності для споживача, якщо в нього не актуалізована відповідна потреба, і не представляє цінності, якщо не може бути отриманий доступ до послуги під час актуалізації потреби. Чим довше час очікування послуги, тем нижче ії цінність для споживача. Подібну залежність можна назвати законом убутної в часі корисності послуги й увести в оборот нову відмітну характеристику послуги: релевантність, яка означає властивість послуги генерувати значиму цінність для споживача тільки в певний момент часу, у момент часу, коли споживач зазнає необхідності в одержанні корисної функції послуги. Ця властивість тісно пов'язана із властивостями «невіддільність від джерела» й «невідчутність», але зміщає акцент із виробництва й споживання послуги на особливості створення цінності. Отже, до складових послуги, як об'єкта управління необхідно додати час, який витрачається на отримання доступу до послуги i для надання послуги в цілому. Відповідно до даної властивості складові послуги як об'єкта управління повинні бути доповнені часом, необхідним для одержання доступу до послуги й для надання послуги в цілому, що у свою чергу можна розглядати як додаткову вигоду від одержання послуги, що підтверджується дослідженнями К. Хаксевера, Б. Рендера, Р. Рассела [11], які розглядають час не тільки як ресурс, а й як вигоду від отримання послуги (табл. 2).

Таблиця 2

Час, як складова послуги

\begin{tabular}{|l|l|}
\hline Категорія & Зміст категорії \\
\hline $\begin{array}{l}\text { Час, як складова } \\
\text { послуги }\end{array}$ & Формування цінності послуги за допомогою часу \\
\hline $\begin{array}{l}\text { Час на отримання } \\
\text { доступу до послуги }\end{array}$ & $\begin{array}{l}\text { Кількість часу, необхідного на пошук і отримання доступу до послуги в момент } \\
\text { виникнення потреби. Чим час менший, тим вище цінність послуги }\end{array}$ \\
\hline $\begin{array}{l}\text { Час на отримання } \\
\text { власне послуги }\end{array}$ & $\begin{array}{l}\text { Кількість часу, необхідного для отримання послуги та задоволення потреби. Чим } \\
\text { час менший, тим вище цінність послуги }\end{array}$ \\
\hline $\begin{array}{l}\text { Час, який дозволяс } \\
\text { економити послуга }\end{array}$ & $\begin{array}{l}\text { Кількість часу, який вивільняється у споживача, якщо він отримуе послугу } \\
\text { (характеризуєтья передачею виконання певної діяльності споживача виконавцю } \\
\text { послуги). Чим час більший, тим вище цінність послуги }\end{array}$ \\
\hline $\begin{array}{l}\text { Час, який діє } \\
\text { результат } \\
\text { надання послуги }\end{array}$ & $\begin{array}{l}\text { Цінність послуги може зберігатися в межах різних відрізків часу, у тому числі: } \\
\text { цінність зараз і на короткий період часу (приклад - готельні послуги, послуги } \\
\text { харчування, розваги); } \\
\text { цінність зараз і на невизначений період часу (приклад - медична допомога, ремонт } \\
\text { побутової техніки); } \\
\text { цінність зараз і на певний тривалий період часу (приклад - послуги кредитування); } \\
\text { цінність у майбутньому (приклад - освіта, страхування). }\end{array}$ \\
\hline
\end{tabular}

Джерело: складено на основі [11] 
В туризмі сфери оздоровлення характеристика «час отримання послуги» набуває особливої значущості. Як тільки особа відчуває потребу в оздоровленні, вона починає комплекс дій, пов’язаних з пошуком шляхів іiі реалізації. Сьогодні існує безліч можливостей реалізувати власні потреби оздоровлення, і всі вони мають як переваги так і недоліки. У будь-якому випадку необхідно витратити час на отримання інформації стосовно аспектів оздоровлення, на порівняння і оцінку варіантів, на прийняття рішення стосовно того чи іншого варіанту вибору. Дані дії, у відповідності до визначення К. Гронроос [15], «спрямовані на вирішення проблем покупця послуги». Тобто, 3 точки зору потенційного споживача, час отримання послуги включає час очікування і своєчасність отримання. I якщо час очікування довгий то втрачається своєчасність отримання, і як наслідок, змінюється рівень цінності послуги і рівень задоволеності споживача.

Необхідно також відзначити, що саме очікування послуги має об'єктивні причини обмеження в часі і впливає на своєчасність їі отримання. Наприклад, очікування послуги оздоровлення батьками, що прагнуть оздоровити власних дітей обмежене календарним часом, що визначається їх режимом праці; очікування послуги оздоровлення осіб, що потребують реабілітації, обмежене регламентом певних процедур оздоровлення від яких суттєво залежить кінцевий результат оздоровлення; очікування послуги оздоровлення особами 3 хронічними захворюваннями обмежене періодами ремісії і т.д. Тобто, очікування послуги та ії вчасне отримання роблять послугу цінною (вигода) в певний момент часу.

Отже, якщо урахувати релевантність послуги, то можна доповнити модель складових послуг Б. Едвардсона (рис.1) ще одним елементом - часом (рис. 2).

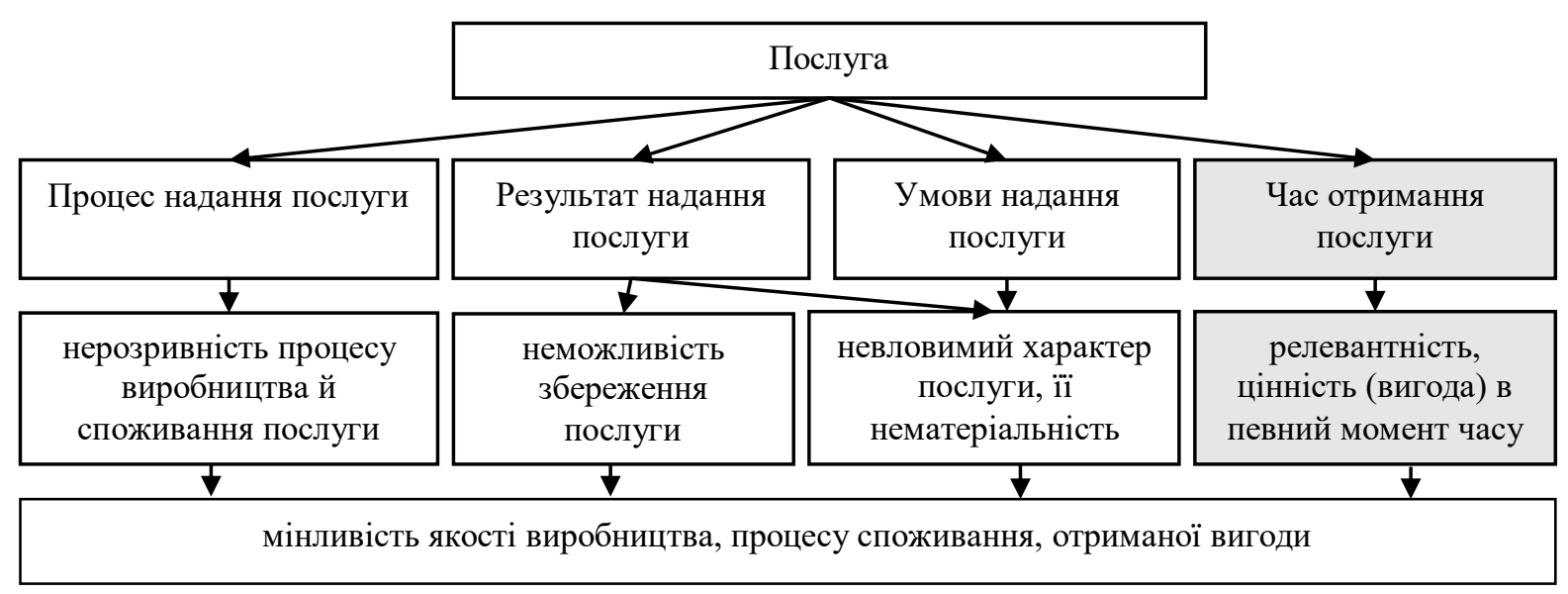

Рис. 2. Доповнена модель складових послуг Б. Едвардсона

Джерело: складено на основі [14] та власних досліджень

Як видно з рис. 2 кожній складовій послуги відповідає певна характеристика, яка змінюється при впливі на відповідну складову.

Проведені дослідження дозволяють уточнити поняття «послуга». Послуга - це дії націлені на одержання нематеріальних i матеріальних економічних благ 3 особливою релевантною оцінкою споживача, і здійснені в результаті взаємодії виробника (виконавця) послуги, споживача й посередників. Послуга як об’єкт управління є сукупністю процесу, результату, умов та часу формування комплексу вигід і благ, які приносять користь споживачу і спрямовані на задоволення його потреб.

Послуги оздоровчого туризму у загальному розумінні представляють собою послуги щодо відновлення здоров'я чи профілактики (попередження) захворювань, що надаються спеціалізованими закладами за наявності певних туристичних ресурсів та інфраструктури. Тобто, дані послуги $є$ часткою ринку рекреаційних послуг.

В Положенні про рекреаційну діяльність у межах територій та об'єктів природно-заповідного фону України затвердженому Наказом Мінприроди України № 330 від 22.06.2009 р. визначено, що «рекреаційною послугою $є$ послуга зі споживчими властивостями і собівартістю, що надається з метою задоволення потреб рекреантів. .... Рекреаційні послуги є продуктом рекреаційної діяльності, яка представлена як діяльність, спрямована на відновлення розумових, духовних і фізичних сил людини шляхом загальнооздоровчого і культурно-пізнавального відпочинку, туризму, санаторно-курортного лікування, аматорського та спортивного рибальства, полювання, тощо» [9]. Отже, рекреаційні послуги виступають надсистемою оздоровчої діяльності, і включають основні функції цієї сфери - лікувальнооздоровчі, профілактичні, функції відпочинку та розваг, мають соціальний, суспільний і економічний зміст. 
Звертаючи увагу на цілі споживачів оздоровчого туризму, сутність оздоровчих послуг необхідно досліджувати як рекреаційні $з$ розділенням за оздоровчо-профілактичним та оздоровчо-лікувальним напрямами. Виходячи 3 такого розуміння послуги оздоровчого туризму представляють собою комплекс своєчасних послуг профілактичного або лікувального характеру, основою яких є специфічні туристичнорекреаційні ресурси, роботи й послуги, певна туристична інфраструктура, сукупність яких сприяє їх реалізації та споживанню.

\section{Висновки}

В результаті дослідження теоретико-методологічних основ категорії «оздоровча послуга» як системоутворюючого фактору розвитку і управління оздоровчим туризмом були виділені наступні властивості:

- оздоровчі послуги знаходяться на перетині туристично-рекреаційної та профілактичнолікувальної діяльності, та виконують соціальні (оздоровчо-профілактичні, оздоровчо-лікувальні функції), суспільні (формування всебічно й гармонійно розвиненої особистості, благоустрій середовища) та економічні функції (реалізація фінансових завдань приватних підприємств, організацій, збільшення доходів бюджетів різних рівнів управління та ін.), що надаються туристичними оздоровчими комплексами на основі єдиних організаційно-правових, екологічних, економічних умов з використанням специфічних природно-лікувальних ресурсів;

- оздоровчі послуги мають загальні для всіх видів послуг ознаки - невловимий характер, нерозривність процесу виробництва й споживання послуги, неможливість збереження послуги, мінливість якості виробництва й процесу споживання; додатковою відмінною характеристикою оздоровчої послуги є релевантність (своєчасність), що забезпечує її цінність (вигоду) в певний момент часу;

- послуги оздоровчого туризму - це рекреаційні послуги з розділенням за оздоровчопрофілактичним та оздоровчо-лікувальним напрямами, що представляють собою комплекс своєчасних послуг профілактичного або лікувального характеру, основою яких $є$ специфічні туристично-рекреаційні ресурси, роботи й послуги, певна туристична інфраструктура, сукупність яких сприяє їх реалізації та споживанню;

- ключовим фактором попиту послуг оздоровчого туризму є рівень задоволеності можливостями і перевагами ресурсного потенціалу туризму сфери оздоровлення.

\section{Список використаної літератури}

1. Ассэль Г. Маркетинг: принципы и стратегия : учебник для вузов. Москва : ИНФРА-М, 1999. $803 \mathrm{c}$.

2. Белл Д. Грядущее постиндустриальное общество. Опыт социального прогнозирования. Москва : «Академия», 1999. 476 с.

3. Берри Л. Особенности маркетинга услуг. Маркетинг услуг. 2006. №3(7). С. 250-258.

4. Бурило Ю. П. Особливості розмежування інформаційних та інформаційно-інфраструктурних робіт і послуг. Науковий вісник Ужгородського наџіонального університету. Серія : Право. Ужгород, 2013. Вип. 22. Ч. І. Т. 2. С. 11-14.

5. Ворачек Х. О состоянии "теории маркетинга услуг". Проблемы теории и практики управления. 2002. №1. С. 99-103.

6. Генеральна угода про торгівлю послугами. URL : http://zakon.rada.gov.ua/cgibin/laws/main.cgi?nreg=981_017.

7. Класифікація видів економічної діяльності (ДК 009:2010) : наказ Держспоживстандарту України від 11.10.2010 p. № 457. URL : http://search.ligazakon.ua/__doc2.nsf/link1/FIN19567.html

8. Котлер Ф. Основы маркетинга. Москва : Бизнес-Книга, 1995. 698 с.

9. Про затвердження Положення про рекреаційну діяльність у межах територій та об'єктів природно-заповідного фону України : наказ Міністерства екології та природних ресурсів України від 22.05.2009 p. №330. URL : http://rada.gov.ua.

10. Про захист прав споживачів : Закон України від 12.05.1991. № 1023-XII Відомості Верховної Ради УРСР. 1991. № 30. Ст. 379.

11. Управление и организация в сфере услуг./ К. Хаксевер и др.; под ред. В.В. Кулибановой. Санкт-Петербург : Питер, 2002. 752 с.

12. Федорченко Н. В. До питання про предмет договору про надання послуг. Держава і право. 2014. № 66. C. 165-173.

13. Шаркова Г. Ю. Науково-теоретичні підходи до встановлення ознак послуги як об'єкта цивільних прав. Держава та регіони. 2013. № 1. С. 123-128.

14. Edvardsson B., Enquist B., Johnston R. Co-creating Customer Value through Hyperreality in the Pre-purchase Service Experience. Journal of Service Research. 2005. Vol. 8. №. 2. P. 149-161. 
15. Gronroos C. A service quality model and its marketing implications. European Journal of Marketing. 1984. Vol. 18. № 4. P. 36-44.

16. Judd R.C. The Case for Refining services. Journal of marketing. 1964. January. P.59.

17. Makarenko S., Oliinyk N., Danko V., Kaplina Y. Formation of an Innovative Competitiveness Management System of the Enterprise: On the Case of Ukraine's Healthcare. Journal of Economics and Management Sciences, 2020. vol. 3, no. 1, p. 1-12.

18. Shandova N., Bylym O. Conceptual approaches to the development of health tourism. The scientific heritage. 2019. № 37. P. 5-18.

19. Shandova N., Voskresenskaya E., Sofiienko A. Innovative Approach to the Formation of a System of Strategic Marketing Management of Tourism Enterprises in Conditions of Market Uncertainty. TEM Journal. Vol.9. № 3. August 2020. P. 1076-1087

\section{References}

1. Assel G. Marketing: principles and strategy: textbook for universities. Moscow: INFRA-M, 1999. $803 \mathrm{p}$. 1999. $476 \mathrm{p}$

2. Bell D. The coming post-industrial society. Social forecasting experience. Moscow: "Academy",

3. Berry L. Features of marketing services. Service marketing. 2006. No. 3 (7). S. 250-258.

4. Burylo Yu. P. Features of differentiation of information and information-infrastructure works and services. Scientific Bulletin of Uzhhorod National University. Series: Right. Uzhhorod, 2013. Issue. 22. Ch. I. T. 2. S. 11-14.

5. Voracek H. On the state of the theory of service marketing. Problems of theory and practice of management. 2002. No. 1. S. 99-103.

6. General agreement on trade in services. URL: http://zakon.rada.gov.ua/cgibin/laws/main.cgi?nreg=981_017.

7. Classification of types of economic activity (DK 009: 2010): order of Derzhspozhyvstandart of Ukraine dated 11.10.2010 № 457. URL: http://search.ligazakon.ua/1_doc2.nsf/link1/FIN19567.html

8. Kotler F. Fundamentals of Marketing. Moscow : Business Book, 1995.698 p.

9. On approval of the Regulations on recreational activities within the territories and objects of the nature reserve background of Ukraine: order of the Ministry of Ecology and Natural Resources of Ukraine dated 22.05.2009 №330. URL: http://rada.gov.ua.

10. On consumer protection: Law of Ukraine of 12.05.1991. № 1023-XII Information of the Verkhovna Rada of the USSR. 1991. № 30. Art. 379.

11. Management and organization in the service sector. / K. Haksever and others; ed. V.V. Kulibanova. St. Petersburg: Peter, 2002.752 p.

12. Fedorchenko NV On the question of the subject of the contract for the provision of services. State and law. 2014. № 66. S. 165-173.

13. Sharkova G. Yu. Scientific and theoretical approaches to establishing the characteristics of the service as an object of civil rights. State and regions. 2013. № 1. S. 123-128.

14. Edvardsson B., Enquist B., Johnston R. Co-creating Customer Value through Hyperreality in the Pre-purchase Service Experience. Journal of Service Research. 2005. Vol. 8. №. 2. P. 149-161.

15. Gronroos C. A service quality model and its marketing implications. European Journal of Marketing. 1984. Vol. 18. № 4. P. 36-44.

16. Judd R.C. The Case for Refining services. Journal of marketing. 1964. January. P.59.

17. Makarenko S., Oliinyk N., Danko V., Kaplina Y. Formation of an Innovative Competitiveness Management System of the Enterprise: On the Case of Ukraine's Healthcare. Journal of Economics and Management Sciences, 2020. vol. 3, no. 1, p. 1-12.

18. Shandova N., Bylym O. Conceptual approaches to the development of health tourism. The scientific heritage. 2019. № 37. P. 5-18.

19. Shandova N., Voskresenskaya E., Sofiienko A. Innovative Approach to the Formation of a System of Strategic Marketing Management of Tourism Enterprises in Conditions of Market Uncertainty. TEM Journal. Vol.9. № 3. August 2020. P. 1076-1087 